\title{
Prevalence of Family History of Cancer among Gastric Cancer Patients at Brazilian National Cancer Institute
}

\author{
Tamara Figueiredo1,2, Maria Teresa Santos Guedes, ${ }^{3,4}$, Luís Paulo Souza e Souza, \\ Antonio Abílio Santa Rosa ${ }^{7}$, Antônio Carlos Accetta ${ }^{8}$, Maria Aparecida de Luca Nascimento ${ }^{4}$, \\ Laís Santiago², Deivite Danilo Ferreira Alcântara9 ${ }^{9}$
}

\footnotetext{
${ }^{1}$ Department of Postgraduate in Adult Health, Federal University of Minas Gerais, Belo Horizonte, Brazil

${ }^{2}$ Department of Radiotherapy, Health Foundation Dilson de Quadros Godinho, Montes Claros, Brazil

${ }^{3}$ National Tumor/DNA Bank National Cancer Institute, Rio de Janeiro, Brazil

${ }^{4}$ Department of Postgraduate Course in Nursing and Biosciences, Federal University of Rio de Janeiro State, Rio de Janeiro, Brazil

${ }^{5}$ Department of Postgraduation in Public Health, Federal University of Minas Gerais, Belo Horizonte, Brazil

${ }^{6}$ Department of Medicine, Federal University of Sao Joao del Rei, São João del Rei, Brazil

${ }^{7}$ Research Department of the Bonsucesso General Hospital, Ethics Committee National Cancer Institute, Rio de Janeiro, Brazil

${ }^{8}$ Department of Abdominal-Pelvic Surgery, National Cancer Institute, Rio de Janeiro, Brazil

${ }^{9}$ Department of Chemotherapy, National Cancer Institute, Rio de Janeiro, Brazil

Email: tamarafigueiredooi@yahoo.com.br
}

How to cite this paper: Figueiredo, T., Guedes, M.T.S., Souza, L.P.S., Rosa, A.A.S., Accetta, A.C., de Luca Nascimento, M.A., Santiago, L. and Alcântara, D.D.F. (2017) Prevalence of Family History of Cancer among Gastric Cancer Patients at Brazilian National Cancer Institute. Health, 9, 25-37. http://dx.doi.org/10.4236/health.2017.91003

Received: October 9, 2016

Accepted: December 27, 2016

Published: December 30, 2016

Copyright (๑) 2017 by authors and Scientific Research Publishing Inc. This work is licensed under the Creative Commons Attribution International License (CC BY 4.0).

http://creativecommons.org/licenses/by/4.0/

\begin{abstract}
Background: Gastric cancer is the third most incident malignancy and the fifth leading cause of death in the world. In Brazil, it is the fourth most common tumour in men and the fifth in women. Familial aggregation of this tumour is being studied and discussed by experts. Aim: Determine the frequency of family history of cancer in patients with gastric cancer, suggesting familial aggregation or increased risk for hereditary cancer syndromes. Methods: This is a retrospective cross-sectional study carried out from January 2011 to March 2015 at the Department of Abdominal and Pelvic Surgery of the Brazilian National Cancer Institute (INCA). Data were collected from electronic medical records and analyzed using SPSS Statistics ${ }^{\otimes}$ version 20. Results: 873 patients with gastric adenocarcinoma were analyzed. A family history of cancer was reported by 451 patients (51.6\%), which reported cancer in 878 relatives, of which $110(12.6 \%)$, reported having more than three relatives with any type of cancer. The most prevalent malignancies among these relatives were gastric cancer (21.3\%) and breast cancer (9.5\%). Conclusion: Most of the patients had cancer family history, being gastric cancer the most common. The high percentage of cancer family history confirms the importance of collecting this information, whose lack reflects professional negligence, as family history study can serve as a low-cost tool, favoring prevention and early diag-
\end{abstract}


nosis, situations where morbidity and mortality are smaller, thus reducing health costs and assistance and preserving lives.

\section{Keywords}

Stomach Neoplasms, Family History, Hereditary, Aggregation, Hospital Records, Cross-Sectional Studies

\section{Introduction}

Gastric cancer is a national and worldwide public health problem [1], prevalent in developing countries, becoming the fifth most prevalent malignancy and the third in mortality in the world, affecting about twice the men [2]. In Brazil, it is the fourth most incident in men and the fifth in women. For the biennium 2016/2017, it is estimated 12,920 new cases in men and 7600 in women [3].

There are many factors associated with this type of cancer, such as: smoking, alcohol consumption, sedentarism, obesity, diet poor in fibers and rich in food preservers (sodium, nitrate and nitrite), infections such as those caused by Helicobacter pylori or Epstein-Barr virus, presence of comorbidities (atrophic gastritis, pernicious anemia), in addition to familial aggregation and hereditary factors [4] [5].

Familial cancer aggregation or "familial cancer" is evidenced by the familial recurrence of some common types of cancer, without a definite pattern of inheritance and high frequency of multiple tumours and at an early age, etiologically caused by a combination of environmental and genetic factors (risk-modifier polymorphisms). Hereditary cancer syndromes, in turn, include hundreds of relatively rare inherited syndromes and of monogenic etiology [5].

A small percentage of gastric tumours occur as part of hereditary predisposition syndromes. In addition to the Hereditary Diffuse Gastric Cancer (HDGC), the main responsible syndromes are Lynch, Peutz-Jeghers, Li-Fraumeni, Cowden, Familial Adenomatous Polyposis (FAP), MUTYH-Associated Polyposis (MAP) and Juvenile Polyposis [6].

There are specific features within a family that suggests the possibility of hereditary cancer syndrome, associated genetic mutations. Among these features there are: cancer diagnosed at early age; autosomal dominant inheritance (successive affected generations); several cases of cancer linked to an individual (breast cancer and ovarian cancer or colon cancer and endometrial cancer); a family member or more than one primary cancer; bilateral cancer in paired organs; occurrence of more than one rare tumour in a family (sarcomas, brain tumors) and male breast cancer [7].

Knowledge of the cancer family history and checking the consistence of this information in daily clinical practice is an important support tool for the genetic counseling of families at risk, hence the importance of knowing it by collection 
and, if possible, confirmation of the information obtained. Documentation of the family health history is the basis of any risk assessment and implementation of preventive measures [7] [8].

Since the positive family history is a recognized risk factor for several chronic diseases like cancer, knowing the family history is important to program the monitoring of people at increased risk of developing malignant tumours and in some cases, in the prevention. This study aimed to determine the frequency of the cancer family history in gastric adenocarcinoma patients suggestive of familial aggregation or at increased risk of syndromes.

\section{Methods}

Retrospective sectional study, carried out at the Abdomino-Pelvic Surgery Division of Brazilian National Cancer Institute, after approval on the Institutional Review Board (IRB) of the Brazilian National Cancer Institute.

Data were collected from electronic medical records of all the patients admitted for treatment of gastric adenocarcinoma in the period from January $1^{\text {st }}, 2011$ to March $13^{\text {th }}$, 2015 resulting in a sample of 873 cases. All the patients with another histologic type of gastric cancer were excluded from this work and also, patients under 18 years old.

For data collection, we used a structured questionnaire with the variables: gender, age, color (according to the classification of the Brazilian Institute of Geography and Statistics-IBGE), educational level, marital status, household income, Performance Status based on the Eastern Cooperative Oncology GroupECOG assigned at the time of hospital admission, blood type and $\mathrm{Rh}$ factor, smoking (defined as anyone who smokes at least 1 cigarette per day for 6 months or more), alcohol intake (an alcohol drinker as anyone who drinks beer, wine and/or hard liquor for at least 3 times per week during 6 months or more), $\mathrm{He}$ licobacter pylori infection, tumor location, histopathological type and degree of cell differentiation, Lauren classification (microscopic), Borrmann classification (macroscopic), presence of signet ring cells, tumor staging (TNM) based on the $7^{\text {th }}$ edition of the International Union Against Cancer-American Joint Committee on Cancer and cancer history family. We considered first-degree (parents, children, and full siblings) and second-degree relatives (grandparents, aunts/ uncles, nieces/nephews, grandchildren, and half siblings).

The data bank was elaborated using SPSS Statistics ${ }^{\mathrm{TM}}$ version 20 (Statistical Package for the Social Sciences). Descriptive analysis was conducted with absolute and relative frequencies, standard deviation, mean and median.

\section{Results}

Sociodemographic status of the patients of our sample is shown in Table 1. Most of the patients in the study were male $(61.4 \%)$, with ages ranging between 23 and 99 years $(B=63.7$ years; median $=64$ years; $\mathrm{SD} \pm 12.5)$, light brown $(42.4 \%)$, married (64.4\%), with low education (77\%) and low household income $(32.9 \%)$. 
Table 1. Sociodemographic characteristics of patients admitted for gastric for treatment of gastric adenocarcinoma $(n=873)$ at the Brazilian National Cancer Institute. Rio de Janeiro, 2015.

\begin{tabular}{|c|c|c|}
\hline Variable & $\mathrm{n}$ & $\%$ \\
\hline \multicolumn{3}{|l|}{ Gender } \\
\hline Female & 337 & 38.6 \\
\hline Male & 536 & 61.4 \\
\hline \multicolumn{3}{|l|}{ Age } \\
\hline $23-40$ & 37 & 4.2 \\
\hline $41-60$ & 279 & 32.0 \\
\hline $61-99$ & 557 & 63.8 \\
\hline \multicolumn{3}{|l|}{ Colour } \\
\hline White & 366 & 41.8 \\
\hline Light Brown & 370 & 42.4 \\
\hline Black & 130 & 15.0 \\
\hline Yellow/Oriental & 2 & 0.2 \\
\hline Not informed & 5 & 0.6 \\
\hline \multicolumn{3}{|l|}{ Marital Status } \\
\hline Unmarried & 99 & 11.3 \\
\hline Married/Consensual Union & 562 & 64.4 \\
\hline Divorced/Separated & 68 & 7.8 \\
\hline Widow & 140 & 16.0 \\
\hline Not informed & 4 & 0.5 \\
\hline \multicolumn{3}{|l|}{ Educational level } \\
\hline None & 502 & 57.5 \\
\hline Elementary & 170 & 19.5 \\
\hline High School & 137 & 15.7 \\
\hline Higher Education & 38 & 4.3 \\
\hline Post graduate & 6 & 0.7 \\
\hline Not informed & 20 & 2.3 \\
\hline \multicolumn{3}{|l|}{ Household income } \\
\hline None & 51 & 5.8 \\
\hline Up to 01 minimum wage & 287 & 32.9 \\
\hline $01-02$ minimum wages & 246 & 28.2 \\
\hline $03-05$ minimum wages & 163 & 18.7 \\
\hline $06-10$ minimum wages & 23 & 2.6 \\
\hline$>10$ minimum wages & 11 & 1.3 \\
\hline Not informed & 92 & 10.5 \\
\hline Total & 873 & 100 \\
\hline
\end{tabular}


With regard to data related to patients's clinical information, (Table 2), most patients had their symptoms started between 3 and 6 months prior to the admission date for oncologic treatment at the institution (26.5\%) and they also had ECOG-Perfomance Status I (54.1\%). Most of them were smokers (49.8\%), drank

Table 2. Clinical characteristics of patients admitted for treatment of gastric adenocarcinoma $(\mathrm{n}=873)$ at Brazilian National Cancer Institute. Rio de Janeiro, 2015.

\begin{tabular}{|c|c|c|}
\hline Variable & $\mathrm{n}$ & $\%$ \\
\hline \multicolumn{3}{|l|}{ Smoking } \\
\hline Yes & 435 & 49.8 \\
\hline No & 338 & 38.7 \\
\hline Not Informed & 100 & 11.5 \\
\hline \multicolumn{3}{|l|}{ Alcohol intake } \\
\hline Yes & 456 & 52.2 \\
\hline No & 317 & 36.3 \\
\hline Not Informed & 100 & 11.5 \\
\hline \multicolumn{3}{|c|}{ ECOG Performance Status } \\
\hline 0 & 88 & 10.1 \\
\hline I & 472 & 54.1 \\
\hline II & 119 & 13.6 \\
\hline III & 31 & 3.6 \\
\hline IV & 6 & 0.6 \\
\hline Not informed & 157 & 18.0 \\
\hline \multicolumn{3}{|l|}{ Blood Type } \\
\hline $\mathrm{O}+$ & 279 & 31.8 \\
\hline $\mathrm{O}-$ & 23 & 2.6 \\
\hline$A+$ & 225 & 25.8 \\
\hline$A-$ & 26 & 3.0 \\
\hline $\mathrm{AB}+$ & 25 & 2.9 \\
\hline $\mathrm{AB}-$ & 2 & 0.2 \\
\hline $\mathrm{B}+$ & 75 & 8.6 \\
\hline $\mathrm{B}-$ & 4 & 0.5 \\
\hline Not informed & 214 & 24.6 \\
\hline \multicolumn{3}{|c|}{ Time from symptom onset } \\
\hline$<3$ months & 108 & 12.4 \\
\hline $3-6$ months & 231 & 26.5 \\
\hline 7 - 9 months & 97 & 11.1 \\
\hline $10-12$ months & 139 & 15.9 \\
\hline$>12$ months & 120 & 13.7 \\
\hline Not Informed & 178 & 20.4 \\
\hline \multicolumn{3}{|c|}{$H$. pylori infection } \\
\hline Yes & 120 & 13.7 \\
\hline No & 213 & 24.4 \\
\hline No informed & 540 & 61.9 \\
\hline Total & 873 & 100 \\
\hline
\end{tabular}


alcoholic drinks (52.2\%) and had blood type O+ (31.8\%). As for the Helicobacter pylori infection, most records (61.9\%) did not include any information about the presence of this infectious agent.

As to the anatomopatholological characteristics (Table 3), most of the tumours affected the distal third of the stomach (30.8\%) with some affecting the middle and distal parts (24.6\%), with histopathological diagnosis of poorly differentiated adenocarcinoma (59.36\%), with signet-ring cell (40\%), Borrmann III (29.3\%), stage IV (22.5\%). Of 873 cases in this sample, 105 were classified according to Lauren's classification as the diffuse type gastric cancer (12\%).

Cancer family history (Table 4) was reported by 451 patients (51.6\%), of which reported of 878 relatives, 551 of first-degree and 327 of second-degree. Of these 451 patients, $110(12.6 \%)$ reported having more than three relatives with any type of cancer. Among them, the most prevalent neoplasia were gastric cancer (21.3\%) and breast cancer (9.5\%).

\section{Discussion}

Sociodemographic characteristics of this study are in accordance with those described in the literature. Gastric cancer affects men more frequently than women, usually over 40 years of age, with a peak incidence ranging between 50 and 70 years, being more prevalent in groups of low socioeconomic status and low educational level [9] [10] [11] [12]. Low socioeconomic status is a variable also associated with other risk factors as high salt intake, Helicobacter pylori infection, and greater difficulty in accessing health services, which results in diagnostic delay, reducing patients' survival and quality of life [13].

Considering clinical and anatomopathological data, our findings corroborate those of the literature [4] [9] [10] [11] [13]. The most common blood group was the group O (34.4\%), as found by Yaghoobi et al. (68.1\%) [14]. However, in other studies the group A+ was the most common [16] [17] [18].

The research shows a high percentage of lack of fulfillment in some variables of interest, similar to those of the clinical and anatomopathological features, affecting some statistical analysis of the study. Statistical analysis is not only a fundamental tool to disclose epidemiological and clinical profile of the diseases, but also plays a pivotal role on the elaboration of indicators, analysis of trends, and indication of priorities and, consequently, planning of actions [19] [20].

Our results show a high percentage of cancer reference in the family history, since more than $50 \%(n=451)$ reported having at least one relative with cancer and 110 patients $(24.4 \%)$ reported having more than three relatives with any type of malignancy. It is well known that about $90 \%$ of gastric tumour cases are sporadic and only $10 \%$ have familial aggregation of cancer [21] [22]. Kawasaki et al. (46.4\%) [23], Minami et al. (26.1\%) [24], Bernini et al. (18.5\%) [25], Yu et al. (9.61\%) [26], La Vechia et al. (12.6\%), [27] e Dhillon et al. (11.1\%) [28] also reported high familial aggregation of cancer. In addition, $51.6 \%$ of patients reported cancer family history in first and second-degree relatives. Bernini et al. (70, 8\%) [25], Kawasaki et al. (46.4\%) [23] and Yu et al. (35.6\%) [26] also reported 
Table 3. Anatomopathological characteristics of patients admitted for treatment of gastric adenocarcinoma $(\mathrm{n}=873)$ at Brazilian National Cancer Institute. Rio de Janeiro, 2015.

\begin{tabular}{|c|c|c|}
\hline Variable & $\mathbf{n}$ & $\%$ \\
\hline \multicolumn{3}{|l|}{ Tumour location } \\
\hline Proximal & 40 & 4.6 \\
\hline Middle & 160 & 18.3 \\
\hline Distal & 269 & 30.8 \\
\hline Proximal and middle & 60 & 6.9 \\
\hline Proximal and distal & 5 & 0.6 \\
\hline Middle and distal & 215 & 24.6 \\
\hline 3 thirds & 82 & 9.4 \\
\hline Not informed & 42 & 4.8 \\
\hline \multicolumn{3}{|l|}{ Cell differentiation grade } \\
\hline Poorly differentiated & 520 & 59.6 \\
\hline Moderately differentiated & 283 & 32.4 \\
\hline Well differentiated & 39 & 4.5 \\
\hline Not informed & 31 & 3.5 \\
\hline \multicolumn{3}{|l|}{ Presence of signet-ring cells } \\
\hline Yes & 349 & 40.0 \\
\hline No & 10 & 1.1 \\
\hline Not informed & 514 & 58.9 \\
\hline \multicolumn{3}{|l|}{ Lauren's classification } \\
\hline Diffuse & 105 & 12.0 \\
\hline Intestinal & 88 & 10.1 \\
\hline Mixed & 10 & 1.1 \\
\hline Not informed & 670 & 76.8 \\
\hline \multicolumn{3}{|l|}{ Borrmann's classification } \\
\hline I & 25 & 2.9 \\
\hline II & 110 & 12.6 \\
\hline III & 256 & 29.3 \\
\hline IV & 154 & 17.6 \\
\hline $\mathrm{V}$ & 6 & 0.7 \\
\hline Not informed & 322 & 36.9 \\
\hline \multicolumn{3}{|l|}{ Staging (TNM) } \\
\hline 0 & 4 & 0.5 \\
\hline I A & 51 & 5.8 \\
\hline I B & 34 & 3.9 \\
\hline IIA & 50 & 5.7 \\
\hline IIB & 41 & 4.7 \\
\hline IIIA & 43 & 4.9 \\
\hline IIIB & 52 & 6.0 \\
\hline IIIC & 69 & 7.9 \\
\hline IV & 196 & 22.5 \\
\hline Not informed & 333 & 38.1 \\
\hline Total & 873 & 100 \\
\hline
\end{tabular}


Table 4. Distribution of the tumours in the first-degree and second-degree relatives $(\mathrm{n}=$ 878 ) of the patients admitted for treatment of gastric adenocarcinoma at the Brazilian National Cancer Institute. Rio de Janeiro, 2015.

\begin{tabular}{|c|c|c|c|c|}
\hline Type of cancer & $\begin{array}{l}\text { Firs-degree } \\
\text { relative (n) }\end{array}$ & $\%$ & $\begin{array}{l}\text { Second-degree } \\
\text { relative }(n)\end{array}$ & $\%$ \\
\hline Gastric & 124 & $22.5 \%$ & 63 & $19.3 \%$ \\
\hline Breast & 57 & $10.3 \%$ & 26 & $8.0 \%$ \\
\hline Prostate & 49 & $8.9 \%$ & 15 & $4.6 \%$ \\
\hline Colorectal & 41 & $7.4 \%$ & 22 & $6.7 \%$ \\
\hline Head and Neck ${ }^{1}$ & 39 & $7.1 \%$ & 41 & $12.5 \%$ \\
\hline Lung & 33 & $6.0 \%$ & 18 & $5.5 \%$ \\
\hline Cervical & 29 & $5.3 \%$ & 19 & $5.8 \%$ \\
\hline Esophageal & 24 & $4.4 \%$ & 5 & $1.5 \%$ \\
\hline Hematological & 27 & $4.9 \%$ & 5 & $1.5 \%$ \\
\hline Liver & 16 & $2.9 \%$ & 6 & $1.8 \%$ \\
\hline Skin & 13 & $2.4 \%$ & 12 & $3.7 \%$ \\
\hline 2 types of cancer ${ }^{2}$ & 12 & $2.2 \%$ & 1 & $0.3 \%$ \\
\hline CNS & 12 & $2.2 \%$ & 10 & $3.1 \%$ \\
\hline Gallbladder & 8 & $1.5 \%$ & 1 & $0.3 \%$ \\
\hline Pancreas & 8 & $1.5 \%$ & 1 & $0.3 \%$ \\
\hline Bone & 8 & $15 \%$ & 6 & $1.8 \%$ \\
\hline Kidney & 8 & $1.5 \%$ & 1 & $0.3 \%$ \\
\hline Penis & 3 & $0.5 \%$ & 1 & $0.3 \%$ \\
\hline Vagina & 3 & $0.5 \%$ & 0 & $0.0 \%$ \\
\hline Bladder & 2 & $0.4 \%$ & 2 & $0.6 \%$ \\
\hline Testicle & 2 & $0.4 \%$ & 0 & $0.0 \%$ \\
\hline Ovary & 1 & $0.2 \%$ & 3 & $0.9 \%$ \\
\hline Vulva & 1 & $0.2 \%$ & 1 & $0.3 \%$ \\
\hline Spleen & 0 & $0.0 \%$ & 1 & $0.3 \%$ \\
\hline Unknown site & 31 & $5.6 \%$ & 67 & $20.5 \%$ \\
\hline Total & 551 & $100 \%$ & 327 & $100 \%$ \\
\hline
\end{tabular}

${ }^{1}$ Head and Neck: Mouth, Laryngeal. ${ }^{2}$ First degree relative: Breast + Laryngeal $(\mathrm{n}=3)$, Bladder + Skin $(\mathrm{n}=$ 1), Breast + Skin $(n=1)$, Breast + Liver $(n=1)$, Gastric + Prostate $(n=1)$, Gastric + Cervical $(n=1)$, Gastric + Lung $(n=1)$, Skin $+H N(n=1)$, Intestine+Prostate $(n=1)$, Prostate + Lung $(n=1)$. Second degree relative: Intestine + Laryngeal $(\mathrm{n}=1)$.

high percentages. These studies are from Italy, Japan and China respectively. In Italy, the problem was related to the genetic susceptibility to the ethnicity. In Japan and China, it was associated with the high incidence of gastric cancer in these countries.

About $1 \%$ to $3 \%$ of diffuse gastric cancers are attributed to the CGDH syndrome [10]. Of 451 patients with cancer family history, 141 patients (31.26\%) had at least one relative at any degree affected by gastric cancer. Relatives of individuals with gastric cancer of the diffuse type have a 7 -fold increased risk of 
developing the same disease, while relatives of individuals with the same intestinal type have a 1.4-fold increased risk of developing gastric adenocarcinoma compared with the remainder of the population [29]. A positive family history of gastric cancer is present in $10 \%$ to $15 \%$ [7] of cases, and is associated with a 1.5 to 3.5 -fold increased risk of developing this neoplasia, compared with the general population [11]-[30]. Individuals with affected first-degree relatives have a 2 to 4 -fold increased risk [30].

In the findings of our study, most of the reported tumours $(35.3 \%)$ in the cancer family history affected some of the digestive tract organs (stomach, esophagus, liver, pancreas, colon and rectum). Due to the lack of documents that confirm consistent recorded information, it emphasizes that the patient presumed the tumour location. Despite the lack of a confirmed diagnosis, these data give rise to suspicion of cancer family risk in the sample used for this study. High percentages like this one in our study were also referred by Kawasaki et al. (70.9\%) [23] and Yu et al. (74.9\%) [26].

Gastric cancer was the most cited tumour by relatives of patients in the sample $(\mathrm{n}=187 ; 21.3 \%)$. Bernini et al. (21.9\%) [25], Kawasaki et al. (40,9\%) [23], Yu et al. (23, 8\%) [26] and Minami et al. (26.1\%) [24], also found high percentages of gastric cancer among relatives of patients in their studies. Dhillon et al. affirm that, even after adjusting for other risk factors, such as age, race, smoking and body mass index [28], the family history of gastric cancer increased the risk of developing this type of tumour in patients.

In our study, breast cancer was the second most common cancer diagnosed among the relatives $(n=83 ; 18.3 \%)$. It can be justified by its high incidence in Brazil and in the world [2] [3]. Breast and gastric cancer can also occur together in other syndromes non-CGDH, such as Li-Fraumeni, Cowden, Peutz-Jeghers and Lynch [31]. In our study, there was no evidence of relationship between breast cancer and HDGC syndrome since lobular histological type was not confirmed in the registered reports of patients and relatives.

The variable age also draw attention to possible investigations, since $37 \mathrm{pa}-$ tients were diagnosed with gastric cancer before age 40 , representing $4.2 \%$ of the whole sample $(n=873)$, which met one of the criteria for suspictions of some hereditary cancer predisposition syndrome [32] [33].

Familial aggregation of cancer shows greater frequency of diffuse type gastric cancer than the intestinal type [29], which is confirmed in our study, since the diffuse-type of adenocarcinoma was diagnosed in 105 patients (12\%). Of these, 12 cases were diagnosed before age 40, fulfilling thus one of the criteria for the CGDH syndrome [7]. It should be noted that missing data in this variable was observed in $76.8 \%(n=670)$ of cases.

This study suffered from limitations for having collected retrospective and secondary data, as well as other studies [24] [25]. For example, we have failed to ascertain the age in which relatives were affected by cancer. Accuracy of the self-reported cancer family history is over $75 \%$ for first-degree relatives. However, it may not be so, as far as more distant relatives are concerned, with varia- 
tions ranging between $50 \%$ and $80 \%$, depending on the type of cancer [8]. Even then, this does not diminish the importance of family history collection, since a positive family history of cancer is necessary for referral of patients and their families to a Clinical Genetics unit in order to receive genetic counseling and specialized follow-up [7] [8] [9] [10].

\section{Conclusions}

We concluded that $51.6 \%$ of the patients had cancer family history in first or second-degree relatives. The reported tumours involved mostly digestive system organs (35.3\%), confirming that family history of digestive system cancer can be a risk factor for gastric cancer, as well as association with lobular breast cancer history.

The high percentage of cancer family history confirms the importance of the data collection. Non-analysis of this information implies a professional negligence, since the family history study can serve as a low-cost tool, favoring prevention and early diagnosis, reducing morbidity, mortality and costs of health assistance and ultimately preserving lives.

Individuals at increased risk for cancer hereditary syndromes should receive specific attention from experts in Cancer Genetics Settings. The professional's view must be holistic and critical, since taking care of the patient means taking care of the family as a whole.

\section{References}

[1] Venerito, M., Link, A., Rokkas, T. and Malfertheiner, P. (2016) Gastric CancerClinical and Epidemiological Aspects. Helicobacter, 21, 39-44.

https://doi.org/10.1111/hel.12339

[2] GLOBOCAN, International Agency for Research on Cancer (IARC) (2012) Stomach Cancer Estimated Incidence, Mortality and Prevalence Worldwide in 2012. http://globocan.iarc.fr/Pages/fact_sheets_cancer.aspx?cancer=stomach

[3] Brasil. Instituto Nacional De Câncer José Alencar Gomes Da Silva (INCA). Estimativa 2016: Incidência de Câncer no Brasil, Coordenação de Prevenção e Vigilância. INCA, Rio de Janeiro, 2016. http://www.inca.gov.br/wcm/dncc/2015/sobre-as-estimativas.asp

[4] Guggenheim, D.E. and Shah, M.A. (2013) Gastric Cancer Epidemiology and Risk Factors. Journal of Surgical Oncology, 107, 230-236. http://onlinelibrary.wiley.com/doi/10.1002/jso.23262/pdf https://doi.org/10.1002/jso.23262

[5] Stoffel, E.M. (2016) Heritable Gastrointestinal Cancer Syndromes. Gastroenterology Clinics of North America, 45, 509-527.

http://www-sciencedirect-com.ez27.periodicos.capes.gov.br/science/article/pii/S088 $\underline{9855316300401}$ https://doi.org/10.1016/j.gtc.2016.04.008

[6] Coburn, N., Seevaratnam, R., Paszat, L., Helyer, L., Law, C., Swallow, C., et al. (2014) Optimal Management of Gastric Cancer: Results from an International RAND/UCLA Expert Panel. Annals of Surgery, 259, 102-108. http://journals.lww.com/annalsofsurgery/pages/articleviewer.aspx?year=2014\&issue $=01000 \&$ article $=00015 \&$ type $=$ abstract 
https://doi.org/10.1097/SLA.0b013e318288dd2b

[7] Syngal, S., Brand, R.E., Church, J.M., Giardiello, M.F., Hampel, H.L. and Burt, R.W. (2015) ACG Clinical Guideline: Genetic Testing and Management of Hereditary Gastrointestinal Cancer Syndromes. The American Journal of Gastroenterology, 110, 223-262. http://www.nature.com/ajg/journal/v110/n2/full/ajg2014435a.html https://doi.org/10.1038/ajg.2014.435

[8] Hampel, H., Bennett, R.L., Buchanan, A., Pearlman, R. and Wiesner, G.L., Guideline Development Group, American College of Medical Genetics and Genomics Professional Practice and Guidelines Committee and National Society of Genetic Counselors Practice Guidelines Committee (2015) A Practice Guideline from the American College of Medical Genetics and Genomics and the National Society of Genetic Counselors: Referral Indications for Cancer Predisposition Assessment. Genetics in Medicine, 17, 70-87.

http://www-nature-com.ez27.periodicos.capes.gov.br/gim/journal/v17/n1/full/gim2 014147a.html https://doi.org/10.1038/gim.2014.147

[9] Guedes, M.T.S., Jesus, J.P., Filho, O.S., Fontenele, R.M. and Sousa, A.I. (2013) Clinical and Epidemiological Profile of Cases of Deaths from Stomach Cancer in the National Cancer Institute, Brazil. Ecancermedicalscience, 8, 445.

http://www.ncbi.nlm.nih.gov/pmc/articles/PMC4118726/

[10] Ang, T.L. and Fock, K.M. (2014) Clinical Epidemiology of Gastric Cancer. Singapore Medical Journal, 55, 621-628.

http://www.ncbi.nlm.nih.gov/pmc/articles/PMC4291998/pdf/SMJ-55-621.pdf https://doi.org/10.11622/smedj.2014174

[11] Ferrari, F. and Reis, M.A. (2013) Study of Risk Factors for Gastric Cancer by Populational Databases Analysis. World Journal of Gastroenterology, 19, 93839391.

https://www.ncbi.nlm.nih.gov/pmc/articles/PMC3882412/pdf/WJG-19-9383.pdf https://doi.org/10.3748/wjg.v19.i48.9383

[12] McCall, M.D., Graham, P.J. and Bathe, O.F. (2016) Quality of Life: A Critical Outcome for All Surgical Treatments of Gastric Cancer. World Journal of Gastroenterology, 22, 1101-1113.

http://www.wjgnet.com/1007-9327/full/v22/i3/1101.htm

https://doi.org/10.3748/wjg.v22.i3.1101

[13] Martel, C., Forman, D. and Plummer, M. (2013) Gastric Cancer: Epidemiology and Risk Factors. Gastroenterology Clinics of North America, 42, 219-240. http://www.sciencedirect.com/science/article/pii/S0889855313000216 https://doi.org/10.1016/j.gtc.2013.01.003

[14] Yaghoobi, M., Rakhshani, N., Sadr, F., Bijarchi, R., Joshaghani, Y., Mohammadkhani, A., Attari, A., Akbari, M.R., Hormazdi, M. and Malekzadeh, R. (2004) Hereditary Risk Factors for the Development of Gastric Cancer in Younger Patients. BMC Gastroenterology, 4, 28. http://www.biomedcentral.com/1471-230X/4/28 https://doi.org/10.1186/1471-230x-4-28

[15] Xu, Y.Q., Jiang, T.W., Cui, Y.H., Zhao, Y.L. and Qiu, L.Q. (2016) Prognostic Value of ABO Blood Group in Patients with Gastric Cancer. Journal of Surgical Research, 201, 188-195.

http://www-sciencedirect-com.ez27.periodicos.capes.gov.br/science/article/pii/S002 2480415010756 https://doi.org/10.1016/j.jss.2015.10.039

[16] Rizzato, C., Kato, I., Plummer, M., Muñoz, N., Stein, A., Jan van Doorn, L., Franceschi, S. and Canzian, F. (2013) Risk of Advanced Gastric Precancerous Lesions in 
Helicobacter pylori Infected Subjects Is Influenced by ABO Blood Group and cagA Status. International Journal of Cancer, 133, 315-322.

http://www.ncbi.nlm.nih.gov/pmc/articles/PMC3656130/ https://doi.org/10.1002/ijc.28019

[17] Wang, Z., Liu, L., Ji, J., Zhang, J., Yan, M., Zhang, J., Liu, B., Zhu, Z. and Yu, Y. (2012) ABO Blood Group System and Gastric Cancer: A Case-Control Study and Meta-Analysis. International Journal of Molecular Sciences, 13, 13308-13321. http://www.ncbi.nlm.nih.gov/pmc/articles/PMC3497328/ https://doi.org/10.3390/ijms131013308

[18] Edgren, G., Hjalgrim, H., Rostgaard, K., Norda, R., Wikman, A., Melbye, M. and Nyrén, O. (2010) Risk of Gastric Cancer and Peptic Ulcers in Relation to ABO Blood Type: A Cohort Study. American Journal of Epidemiology, 172, 1280-1285. http://aje.oxfordjournals.org/content/172/11/1280.full.pdf+html https://doi.org/10.1093/aje/kwq299

[19] Grabois, M.F., Souza, M.C., Guimarães, R.M. and Otero, U.B. (2014) Completude da informação "Ocupação" nos Registros Hospitalares de Câncer do Brasil: Bases para a vigilância do câncer relacionado ao trabalho. Revista Brasileira de Cancerologia, 60, 207-214.

http://www.inca.gov.br/rbc/n_60/v03/pdf/04-artigo-completude-da-informacao-oc upacao-nos-registros-hospitalares-de-cancer-do-brasil-bases-para-a-vigilancia-do-c ancer-relacionado-ao-trabalho.pdf

[20] Rebelo, P.A.P. (2014) A Informação sobre a ocupação do paciente nos Registros hospitalares de câncer no Brasil. Revista Brasileira de Cancerologia, 60, 239-245. http://www.inca.gov.br/rbc/n_60/v03/pdf/08-artigo-a-informacao-sobre-a-ocupaca o-do-paciente-nos-registros-hospitalares-de-cancer-no-brasil.pdf

[21] Oliveira, C., Seruca, R. and Carneiro, F. (2006) Genetics, Pathology, and Clinics of Familial Gastric Cancer. International Journal of Surgical Pathology, 14, 21-33.

http://ijs.sagepub.com/content/14/1/21.long https://doi.org/10.1177/106689690601400105

[22] Corso, G., Marrelli, D. and Roviello, F. (2011) Familial Gastric Cancer: Update for Practice Management. Familial Cancer, 10, 391-396.

http://link.springer.com/article/10.1007\%2Fs10689-010-9410-1 https://doi.org/10.1007/s10689-010-9410-1

[23] Kawasaki, K., Kanemitsu, K., Yasuda, T., Kamigaki, T., Kuroda, D. and Kuroda, Y. (2007) Family History of Cancer in Japanese Gastric Cancer Patients. Gastric Cancer, 10, 173-175. http://link.springer.com/article/10.1007\%2Fs10120-007-0427-6 https://doi.org/10.1007/s10120-007-0427-6

[24] Minami, Y., Kawai, M., Fujiya, T., Suzuki, M., Noguchi, T., Yamanami, H., Kakugawa, Y. and Nishin, Y. (2015) Family History, Body Mass Index and Survival in Japanese Patients with Stomach Cancer: A Prospective Study. International Journal of Cancer, 136, 411-424.

http://onlinelibrary.wiley.com/doi/10.1002/ijc.29001/abstract;jsessionid=6406F74E2 AC57CD16161E105A21CA6CE.f03t02

https://doi.org/10.1002/ijc.29001

[25] Bernini, M., Barbi, S., Roviello, F., Scarpa, A., Moore, P., Pedrazzani, C., Beghell, S., Marrelli, D. and Manzoni, G. (2006) Family History of Gastric Cancer: A Correlation between Epidemiologic Findings and Clinical Data. Gastric Cancer, 9, 9-13. http://link.springer.com/article/10.1007\%2Fs10120-005-0350-7 https://doi.org/10.1007/s10120-005-0350-7

[26] Yu, J., Fu, B. and Zhao, Q. (2013) Family History of Malignant Neoplasm and Its Relation with Clinicopathologic Features of Gastric Cancer Patients. World Journal 
of Surgical Oncology, 11, 201.

http://wjso.biomedcentral.com/articles/10.1186/1477-7819-11-201 https://doi.org/10.1186/1477-7819-11-201

[27] La Vecchia, C., Negri, E., Franceschi, S. and Gentile, A. (1992) Family History and Risk of Stomach Cancer and Colorectal Cancer. Cancer, 70, 50-55. http://onlinelibrary.wiley.com/doi/10.1002/1097-0142(19920701)70:1\%3C50::AIDCNCR2820700109\%3E3.0.CO;2-I/pdf https://doi.org/10.1002/1097-0142(19920701)70:1<50::AID-CNCR2820700109>3.0. CO;2-I

[28] Dhillon, P.K., Farrow, D.C., Vaughan, T.L., Chow, W.H., Risch, H.A., Gammon, M.D., et al. (2001) Family History of Cancer and Risk of Esophageal and Gastric Cancers in the United States. International Journal of Cancer, 93, 148-152.

http://onlinelibrary.wiley.com/doi/10.1002/ijc.1294/pdf https://doi.org/10.1002/ijc.1294

[29] Barber, M., Fitzgerald, R.C. and Caldas, C. (2006) Familial Gastric Cancer-Clinical Management. Best Practice \& Research Clinical Gastroenterology, 20, 735-743. http://www.bpgastro.com/article/S1521-6918(06)00025-4/fulltext https://doi.org/10.1016/j.bpg.2006.03.014

[30] Yaghoobi, M., Bijarchi, M. and Narod, S.A. (2010) Family History and the Risk of Gastric Cancer. British Journal of Cancer, 102, 237-242.

http://www.nature.com/bjc/journal/v102/n2/full/6605380a.html https://doi.org/10.1038/sj.bjc.6605380

[31] Agnese, D.M. and Pollock, R.E. (2016) Breast Cancer Genetic Counseling: A Surgeon's Perspective. Frontiers in Surgery, 3, 4.

https://www.ncbi.nlm.nih.gov.ez27.periodicos.capes.gov.br/pmc/articles/PMC47298 81/pdf/fsurg-03-00004.pdf https://doi.org/10.3389/fsurg.2016.00004

[32] Tan, R.Y.C. and Ngeow, J. (2015) Hereditary Diffuse Gastric Cancer: What the Clinician Should Know. World Journal of Gastrointestinal Oncology, 7, 153-160.

http://www.wjgnet.com/1948-5204/pdf/v7/i9/153.pdf https://doi.org/10.4251/wjgo.v7.i9.153

[33] Sugimoto, S., Komatsu, H., Morohoshi, Y. and Kanai, T. (2015) Recognition of and Recent Issues in Hereditary Diffuse Gastric Cancer. Journal of Gastroenterology, 50, 831-843. http://link.springer.com/article/10.1007\%2Fs00535-015-1093-9 https://doi.org/10.1007/s00535-015-1093-9 
Submit or recommend next manuscript to SCIRP and we will provide best service for you:

Accepting pre-submission inquiries through Email, Facebook, LinkedIn, Twitter, etc. A wide selection of journals (inclusive of 9 subjects, more than 200 journals)

Providing 24-hour high-quality service

User-friendly online submission system

Fair and swift peer-review system

Efficient typesetting and proofreading procedure

Display of the result of downloads and visits, as well as the number of cited articles Maximum dissemination of your research work

Submit your manuscript at: http://papersubmission.scirp.org/

Or contact health@scirp.org 